\title{
Review of "Labouring Feminisms and Feminist Working-Class History in North America and Beyond," 29 September-2 October 2005, Munk Centre for International Studies at the University of Toronto.
}

\section{Rhonda L. Hinther}

What is labour history? What is feminist history? How do they intersect? What have these intersections meant historically? Historiographically? Through what means are scholars interrogating labour history, feminist history, labouring feminisms? These were some of the key issues confronted, challenged, and addressed at the groundbreaking conference, "Labouring Feminism and Feminist Working-Class History in North America and Beyond" (or, "Labouring Feminisms," as it came to be called by many participants), held 29 September-2 October 2005 at the Munk Centre for International Studies at the University of Toronto.

As its title suggests, the conference brought together a diversity of scholars from Canada, the US, Australia, Germany, Mexico, and Britain. The consensus that emerged from the variety of papers, panellists, and presentations is that labouring feminism is a pluralistic concept, a "many splendoured thing." Panel sessions featured a variety of topics: "Labour, Race, Empire"; "Labouring and Consuming Bodies"; "Working Class Masculinities and Rethinking the "Manly Man' in Labour History"; "Culture, Representation, and Politics on Display"; and "Trade Union Feminism-Its Presence and Its Absence," to name but a few. The variety of methodologies and sources scholars in attendance used and the diverse means through which they presented and diffused their findings was especially welcome to see. Varpu Lindstrom's Letters from Karelia, a film that explores the often tragic circumstances encountered by Finns who journeyed to Karelia in the 1930s in support of the Soviet experiment, was an engaging example of film as a means of disseminating research and exploring labour activism and its intergenerational consequences.

One of the particular strengths of the conference was the way in which it welcomed and integrated the work of "new scholars" with that of more seasoned academics. While academically rigorous, it nonetheless created a friendly and informal environment where connections between generations of scholars could be made. An asset to the often crowded conference was the lounge of the Munk Centre, an environment of easy approachability which was, as a result, the site of many post-panel or post-plenary "cross-generational" discussions. Scheduled free time and social events, like the Saturday night conference party and dance, also facilitated relaxed scholarly interaction, a feat at which many conferences can fail. 


\section{Hinther}

While the conference was a chance to explore what has and is being done in and with feminist labour history it was more importantly, perhaps, an opportunity to highlight the need for more comparative (particularly transnational) approaches in the field. While the obvious links between many panel papers highlighted the value of this type of inquiry, the presentations at the plenary "Labour Feminism and Women's Activities: National, Transnational, and Comparative Perspectives" drove the issue home. Papers by Karen Hunt ("Rethinking Communist, Socialist, and Other Radical Women in Britain and Europe"), Jennifer Guglielmo and Franca Iacovetta ("Historicizing Transnational Working-Class Immigrant Feminisms in the US and Canada"), and Wendy Goldman ("Lesson of Proletarian Feminism in Power and Defeat: The Soviet Union"), in particular, illustrated existing historical feminist parallels and the value of comparative international approaches for devising methodologies and strategizing for change.

Clearly, the time was ripe for this sort of conference. Sessions were often packed (to the point that an overflow room with closed-circuit television was necessary for plenary panels). The high attendance and diversity of participants suggests ongoing widespread cross-disciplinary interest in feminist labour history. It was especially refreshing to see the array of scholarly activity that challenged and expanded traditional boundaries of what constituted "labour," "work," "activism," and, perhaps most importantly, "feminism." This was evident in the array of papers dealing with the labouring experiences and activism of Aboriginal women, women of colour, and women with disabilities who have, too often in the past, been situated outside or excluded from meaningful and inclusive feminist and labour discourse. Groundbreaking and insightful work was also evident in panels such as "The Body and Rethinking Working Class History"; "Whose Bodies? Whose Rights? Politics of Labour and the State"; and "Producing Sex" which interrogated the body and bodies-in prison, in morgues, on stage, and in uniforms - as venues and symbols for exploitation, resistance, and activism.

Because of the sheer variety of offerings, it was often an overwhelming task to try to choose which of the panels to attend. Organizers were right to limit parallel session papers to ten minutes, and session chairs should be commended for the regularity with which the ten-minute rule was enforced. Additional time for questions would have been useful, however. Fewer panels in each parallel session would have also been helpful. Too often it was difficult to choose which of the four panels to attend-there was simply too much to see in too short a time. Hopefully future versions-and there definitely should be future versions —of "Labouring Feminisms" will see one or two additional days added to the schedule to permit participants to hear more papers.

Of course, these minor shortcomings did not affect the overall impact of "Labouring Feminisms." Participants routinely expressed much enthusiasm, 
and many indicated that they could feel that they were a part of something biga key development and turning point in working-class feminist historical studies and activism. Overall, "Labouring Feminisms" was an exciting and engaging event and an important springboard for the expansion of transnational feminist labour history. 